\title{
Economic benefits of sport fishing in Los Cabos, Mexico: is the relative abundance a determinant?
}

\author{
V. A. Hernández-Trejo ${ }^{1}$, G. Ponce-Díaz Germán ${ }^{2}$, D. Lluch-Belda ${ }^{2}$ \\ \& L. F. Beltrán-Morales ${ }^{3}$ \\ ${ }^{1}$ Universidad Autónoma de Baja California Sur, Mexico \\ ${ }^{2}$ Centro Interdisciplinario de Ciencias Marinas, Mexico \\ ${ }^{3}$ Centro de Investigaciones Biológicas del Noroeste, Mexico
}

\begin{abstract}
Los Cabos is the main tourism destination in Baja California Sur with almost 1.19 million visitors in 2009. Its early development is linked to sport fishing practice since 1960 , mainly for two reasons. The first one refers to the high likelihood of catching. The second is related to the abundance of sport fishing species (blue, striped and black marlin; sailfish, dolphin fish, yellowfin tuna, wahoo, roosterfish and jack mackerel), which are present and are highly abundant throughout the year. The study aims to estimate the economic benefits of sport fishing in Los Cabos by applying an economic valuation technique known as travel costs. The study has two basic assumptions; first, travel cost method allows estimating more conservative benefits than the preceded studies for this activity. The second assumption is that the relative abundance of sport fishing species is relevant within the demand model for sport fishing trips. The purpose of valuation is to estimate the willingness to pay for access (WTP) the site and subsequently the economic benefit. Count models, like Poisson, are generally used in travel cost method to estimate the WTP to access the site. The models incorporate arguments like cost of the fishing trip, income, other socioeconomic variables and the catch per unit effort (CPUE). CPUE is considered an appropriate index to measure the relative abundance of sport fishing species. Several Poisson models were estimated to calculate the individual WTP, with values from 22.27 to 70.55 dollars. The economic benefits of sport fishing in Los Cabos for the estimated models are between 2.10 and 6.65 million dollars. The value of WTP can be used to propose modifications to
\end{abstract}


the access fees, and the collected amount may be oriented to enforce conservation, protection and management actions.

Keywords: economic valuation, travel cost, sport fishing, Los Cabos, catch per unit effort.

\section{Introduction}

Sport fishing is a touristic activity that has established with time. This activity is practiced by people from different countries around the world and it is done mostly in the coasts. There are places where there is an increment of fishermen who gather when the abundance of sport fishing species is high for this activity. Places like Cairns, Australia; Bay of Island, New Zeland; Kailua-Kona, Hawai y Cabo Blanco, Peru.

Chávez-Comparan [1] mention that the practice of recreational fishing in Mexico is one of the leisure activities that offers the greatest natural attractions, because the country has wide variety of species for that activity. In Mexico, sport fishing generates important economic benefits. The National Commission of Aquaculture and Fisheries (CONAPESCA [2]) calculates the benefits of sports fishing in Mexico around two thousand million dollars (MD). The economic flow generated by this activity generates a multiplier effect in three sectors of the economy: i) the tourist (because of the services of hospitality, restaurants, travel agencies and transport), ii) fishing (through the tour operators, supply of materials and port facilities) and, iii) the industrial (because of the manufacture of ships, equipment and accessories, taxidermy and in general the related industry).

In Mexico, sport fishing is practiced in tourist resorts like Acapulco and Ixtapa Zihuatanejo in Guerrero; Puerto Vallarta in Jalisco; Manzanillo at Colima; Mazatlan in Sinaloa and Los Cabos located in Baja California Sur. Among the principal species for sport fishing are billfishes such as sail fish, striped, blue and black marlin. The minor sport fishing species are principally yellow fin tuna, wahoo, roosterfish and jack mackerel. The billfishes species are the most coveted by the sport fisherman because their strength and size (Klett-Traulsen et al. [3]). Gerhard and Gulick [4] state that Los Cabos owes its tourist calling principally due to two factors: i) the raise of the sport activity and ii) because of the species destined for this activity is one of the principal attractions that motivate tourists to travel to this destination Pérez-Valencia [5] .

Sport fishing in Baja California Sur (BCS) is concentrated mainly in Los Cabos area for three reasons: i) it has tourism infrastructure and trained personnel to attend this type of demand, ii) minimal seasonal changes in the quantity of different sport fishing species; and iii) the presence of all fishing species along the year (Ponce-Diaz et al. [6]). These factors associated the demand for recreational ecosystem services provide for the sport fishing species in a positive with the increase of the activity (Hernandez-Trejo et al. [7]). At the end of last century sport fishing has become a strong branch of economic activity in Los Cabos. 
In 2010 the Harbor Master of Cabo San Lucas reports 32,166 trips of sport fishing and 94,218 fishermen aboard, however there isn't a report on the catch rate. Catch rate is an important variable to be considered in any study of sport fishing since it is highly related to the number of fishing trips (Ortega-Garcia et al. [8]). A (positive or negative) variation in the catch rate of the species meant to sport fishing could affect in two aspects: i) one variation in the sport fishing travel demands in the zone; and ii) one variation in the perceived recreational benefit by the sport fisherman.

To measure the impact that the variation in catch rates has in the welfare of sport fishermen, can be calculated using economic valuation techniques suggested by the environmental economics. The existing value among the natural attributes of a place and the productive activities that take place therein can be expressed in terms of their ecosystem services, because the value of the ecosystem services is its contribution to social welfare. This value can be expressed by the concept of economic value proposed by Tuner et al. [9]. To find the economic value of an element or the ecosystem service, it has to be completely identified and then different valuation methods can be used $[10,11]$.

The present study aims to incorporate the relative abundance of species of sport fishing (measured by catch per unit effort [CPUE]) as a determinant of the demand per sport fishing trips in the area of Los Cabos and prove if they have influenced over the recreational economic benefits generated by the activity.

\section{Background: aluation of sport fishing in Los Cabos}

The first economic valuation study for sport fishing in Los Cabos is the one of Ditton and his collaborators [12], they used contingent valuation to assess the activity of sport fishing in Los Cabos; the study includes variables such as the willingness to pay (WTP), income, travel cost, years of experience and the fishermen school level; they obtain a recreational value of the activity of about 15.5 (MD). Thereafter the Billfish Foundation [13] conducted a study to estimate the multiplier of the activity and subsequently calculate the economic benefits generated by the sport fishing in Los Cabos, getting a benefit of 1.13 MD.

None of the previous mentioned studies include environmental determinants in their estimations. A study that applied the individual travel cost method (TC) and incorporates the catch rate (CR) is Alberinni's et al. [14], when they incorporate the $\mathrm{CR}$ in the model is possible to observe how the consumer surplus changes due to a variation in the $\mathrm{CR}$, without changing the prices. It also analyses contingent scenarios about the abundance of sport fishing species, where two situations are handled: i) the status quo and, ii) an increment of the biomass, based in this two scenarios it is possible to visualize the changes in the welfare derived from a proper management program of sport fishing species.

Economic valuation is a tool that can help to design economical instruments capable of changing patterns of production or consumption. It also supports management plans or other instruments for ecosystem services conservation. The assessment is useful for estimating the economic amount of possible damages 
about the ecosystem services and/or the benefits of conservation actions (Seenprachawong [15]).

\section{Economic valuation methods}

Economic valuation plays an important role in decisions concerning the use of natural resources. It allows measuring and comparing -monetarily-, the gain or loss of the welfare that a person will experience, or the society, because of an improvement or environmental damage. It can contribute to determine an approximate amount for the service provision of environmental services or compensations caused by environmental damages. Also contributes to propose economic instruments aimed to modify production or consumption patterns, and strengthens the design and implementation of conservation and management plans of the ecosystem services. The economic valuation can be useful to evaluate the impact or welfare of an environmental policy.

The contribution made by the tradeoffs of ecosystem services to the welfare is where its economic value lies. If not perceived contribution to welfare, the value assigned to ecosystem services will be void. The existing value between the ecosystem services and the productive activities- including the recreational onescan be expressed in monetary terms through the tradeoffs that exist among them $[16,17]$; this tradeoffs can be expressed by means of the concept of economic value proposed by the environmental economics. To find the economic value of an element or service of the ecosystem different valuation methods can be used.

Here are two basic approaches in the context of environmental economy: i) market methods and ii) non market methods. The approach addressed in the study are the methods that asset environmental value through demand curve (market methods), known as expressed and revealed preferences methods. For the expressed preferences methods we have the contingent valuation method; and for the revealed preference methods there are two methods, travel cost and hedonic prices method. All of them measure variations in the welfare by the consumer surplus.

For recreational benefits (direct use values) given by the ecosystem services of the sport fishing species, one method proposed to be able to value them monetarily is the travel cost method (TC). This method is commonly used to calculate the benefits derive from visitors to sites that protect natural resources with recreational use values. TC asks directly to the users or visitor for their travel costs and expenses incurred during their stay in the site.

Harold Hotteling (1947) suggested the use of the TC to estimate entrance fees to national parks in the United States of America (USA), however it can also be used to asses specific characteristics or attributes of the site. The substance of the method is due to the decision of traveling to a place to enjoy its recreational services (Habb and McConnell [18]). Visitors to the site will incur into travel costs, payment of entrances fees, payments made at the site and other expenses related with a given level of visits Azqueta-Oyarzun [19]; so it is considered a model of demand for a recreational site. 


\section{Travel cost method}

TC is based on cost variations of the expenses that cause differences in the quantities demanded, which allows estimate the cost of demand per trip at different cost levels. TC also assumes that individual recognizes his preferences under conditions of complete certainty; but there are elements in those preferences that are unobservable, neither accessible for the modeler. As the unknown elements of the preferences can be assumed to be stochastic and be included in an error component in the models.

Individual TC has five principal assumptions: i) travel and time is proxy variables for the price of a recreational trip; ii) travel time is neutral, providing no utility or disutility; iii) the decision unit is trips of equal length across the site for each household; iv) the trips are single purpose trips, taken to the recreation site for the purpose of recreation and $\mathrm{v}$ ) the quantity consumed $\left(x_{i j}\right)$ is trips the same place for all consumers.

Same authors mention, that the demand curve estimated by TC shows the availability of the individual to accept improvements in the site or how he values damages to the site. This provision is measured by the number or trips that the individual would be willing to make if those changes would occur. The behavior of the individual, about the various changes in the recreational sites, can be obtained by the travel cost, and socioeconomic variables incorporated in the model.

The individual model of demand starts from a time allocation and income given by a function of a generic demand function for a single site. Assumes that the individual $i$ chooses $x_{i j}$; where $j$ is the number of trips to the site $\forall j=1,2, \ldots$. The cost for a round trip is $c_{i j}$. The individual also consumes a composition of assets associated with travel $\mathbf{z} j$, also called weak complementary assets [20]. TC assumes that the individual has two restrictions: i) income, $y_{i}\left(\sum_{j=1}^{n} x_{i j} c_{i j}+z_{i} \leq y_{i}\right)$ and ii) time $\sum_{j=1}^{n} x_{i j}+t_{i j}+h_{i}=T_{i}$ where $t_{i}$ is the travel time to the site $j ; h$ are the working hours and $T$ is the total available time. And it is assumed that the time devoted in each site visit is the same.

The demand of the individual I for the site $\mathrm{j}$, with explicit arguments is given by $x_{i 1}=f_{1}\left(c_{i 1}+t_{i 1} w_{i}, \ldots, c_{i n}+t_{i n} w_{i}, q_{1} \ldots q_{n}, y_{i}^{f}\right)$, where $y_{i}^{f}$ is the full income of the individual $\left(y_{i}^{f}=y_{i}^{0}+w_{i} T_{i}\right)$; or the amount of money that someone can make if he works all the time he is available, $w_{\mathrm{i}}$, the income after taxes, each $q_{j}$ is the exogenous quality for the $j$-nth site, and $y_{i}^{0}$ is the adjusted income of the individual $i$ through $y_{i}^{0}=y_{i}+w_{i} h_{i}$ where $y_{i}$ is the individual income.

Once the general demand model has been defined, the parameters associated to each determinant to the numbers of travels to the site can be estimated. The most common model in the analysis in the TC is the count model Poisson. For 
estimates we define the demand curve for the individual site $i$ in a given population as

$$
x_{i}^{*}=f(\mathbf{z} i)+\varepsilon i,
$$

where $\mathbf{z}_{i}=\left(p_{i j}, j=1, \ldots, n ; q_{j}, j=1, \ldots, n, y_{i}^{f}\right)$ and $p_{i j}=c_{i j}+w_{i} t_{i j}$.

Poisson models specify the amount, trips, as an integer random, not negative, with an independent mean of exogenous regressors. The functional form of the demand for this model is typically exponential. For single site models, the general count model is written as follows $\operatorname{Pr}\left(x_{i}=n\right)=f\left(n, \mathbf{z}_{i}, \beta\right)$, $\mathrm{n}=0,1,2, \ldots$, and the probability density function (PDF) is given by $\operatorname{Pr}\left(x_{i}=n\right)=\left(e^{-\lambda_{i}} \lambda_{i}^{n} / n !\right) ; n=0,1,2, \ldots ;$ where $\lambda \mathrm{i}>0$ and it is specified as an exponential function $\lambda_{i}=\exp \left(\mathbf{z}_{i}, \beta\right)$. Once the parameter estimates associates to the vector $\mathbf{z}$, the willingness to pay to access the site (WTP) for the Poisson model can be calculated by equation (1).

$$
W T P(\text { access })=\int_{C^{0}}^{\infty} e^{\beta_{0}+\beta_{1} C} d C=\left[\frac{e^{\beta_{0}+\beta_{1} C}}{\beta_{1}}\right]_{C=C^{0}}^{C \rightarrow \infty}=-\frac{x}{\beta_{1}}
$$

Within the general demand model, the CPUE was incorporated by taking the monthly registries of this variable reported by the fishing fleet that operates in the area. About that Hanley et al. [21] and Maunder et al. [22], mention that the CPUE is used as a suitable index to measure the relative abundance of fisheries stock, which can also be used in the sport fisheries.

\section{Data}

Stratified random sampling was used considering each sampling month as a stratum, with a confidence level of $95 \%$ and an estimation error of $4 \%$. The sample analyzed was 467 individual who travel to Los Cabos to practice sport fishing between August 2010 and September 2011; the response rate of the survey was $81 \%$. The $80 \%$ of the sample visitors declare to come from the USA, 9\% from Canada and 7\% from Mexico, from them 34\% live in California; $97 \%$ of the people interviewed were male. With an average age of 34 years old, $72 \%$ locate their educational level in graduate level (including master and Ph.D.) and report a yearly average income of 137 thousand and 740 dollars.

Related to the activity of sport fishing, $85 \%$ states that they didn't participate in fishing tournaments, only $43 \%$ of them declared that the reason of their visit is sport fishing and $47 \%$ considers it as a very important element in their visit. $56 \%$ of the surveyed considered themselves as expert fishermen, $80 \%$ rented the boat in which they went fishing, only $13 \%$ of the fishermen didn't captured any species in their trip and $66 \%$ acquired a fishing license. The average days of fishing was two days, with a total travel cost and an average cost for the fishing trip of 4,783 and 782 dollars respectively. 


\section{Results}

To estimate the benefits of the sport fishing in Los Cabos the individual TC was used. The results show that the demand function is not linear in the price $(p)$ or travel cost $(t c)$, but is linear in the other attributes; income $(y)$ and catch per effort unit (срие).

$$
v=c+\beta_{1} \frac{1}{p}+\beta_{2} y+\beta_{3} \text { cpue }+\varepsilon
$$

Where $v$ is the independent variable representing the number of trips of sport fishing at Los Cabos and $\varepsilon$ is the stochastic term. Thus the equation (2) becomes into an econometric model. This model is estimated $\mathrm{d}$ with the collected data in the survey, including the variables mentioned before and other individual attributes of the fishermen interviewed. (Table 1)

Table 1: $\quad$ Variables in the model estimates.

\begin{tabular}{|l|l|}
\hline Variable & Description \\
\hline invtc & $\frac{1}{t c}$ of the travel cost of fishing of the $i$ - $n$th individual \\
\hline cpue & $\begin{array}{l}\text { Catch per unit effort reported by the fleet in the area reported for } \\
\text { the week of the interview }\end{array}$ \\
\hline ly & Natural logarithm of the income of $i$ - $n t h$ individual \\
\hline reason & $\begin{array}{l}\text { Principal reason of the visit to Los Cabos: 1: fishing; 2: vacation; } \\
\text { 3: other }\end{array}$ \\
\hline license & $\begin{array}{l}\text { Type of license acquired by the fishermen. 1: daily, 2: weekly, 3: } \\
\text { monthly y 4: yearly }\end{array}$ \\
\hline skunk & $\begin{array}{l}\text { Take the value from 1: if the fisherman didn't catch any fish in } \\
\text { their fishing trip, 0: other form }\end{array}$ \\
\hline impfish & $\begin{array}{l}\text { Take the value from 1:when the sport fishing is very important for } \\
\text { the reason of the trip, 0: other form }\end{array}$ \\
\hline
\end{tabular}

Problems of heteroskedasticity detected in the estimates were corrected by the reciprocal of the cost (invtc), as the correction was made the estimation of the WTP cannot be done by the equation (3). According to Christiernsson [23] to calculate the WTP there are steps to be made: 1) estimate the elasticity of the travel cost $\left(\eta_{t c}\right)$ by $-\beta_{t c} /\left(T_{a} \cdot t c_{a}\right)$; where $\beta_{t c}$ is the coefficient of invtc, $T_{a}$ and $t c_{a}$ are the average of the visits and the travel cost respectively, and 2) calculate de WTP by $-T_{i} /-\eta_{t c}$; where $T_{i}$ is the number of travels per individual. The calculated elasticity for the models has an inelastic behaviour.

The critical values (vc) of the Log-likelihood for the corresponding $\alpha$ value to determine the effectiveness of the estimates are: i) if $\alpha=0.05$; then $\mathrm{vc}=-3.84$; ii) $\alpha 0.01$; $\mathrm{vc}=-6.63$; iii) $\alpha 0.001$; $\mathrm{vc}=-10.83$ and iv) $\alpha 0.0001$; $\mathrm{vc}=-15.13$ (Rayson 
and Garside [24]). Having presented the above it can be said that the estimated models are robust and efficient up to $99 \%$ of confidence.

Table 2: $\quad$ Poisson's estimates.

\begin{tabular}{|c|c|c|c|c|c|c|}
\hline \multirow{3}{*}{ Variable } & \multicolumn{6}{|c|}{ Model } \\
\hline & \multicolumn{2}{|c|}{ Extended I } & \multicolumn{2}{|c|}{ Extended II } & \multicolumn{2}{|c|}{ Extended III } \\
\hline & Coef. & $\mathrm{P}>\mathrm{Z}$ & Coef. & $\mathrm{P}>\mathrm{Z}$ & Coef. & $\mathrm{P}>\mathrm{Z}$ \\
\hline invtc & -130.7220 & 0.0000 & -103.3969 & 0.0000 & -50.2207 & 0.0020 \\
\hline срие & 2.0213 & 0.0000 & 2.2925 & 0.0000 & 0.6905 & 0.0570 \\
\hline ly & ---- & ---- & -8.7552 & 0.0000 & -9.7620 & 0.0000 \\
\hline reason & ---- & --- & ---- & ---- & -0.3655 & 0.0000 \\
\hline license & $\begin{array}{ll}--- \\
---1\end{array}$ & ---- & ---- & ---- & 0.1380 & 0.0010 \\
\hline skunk & $\begin{array}{ll}--- \\
--1\end{array}$ & ---- & - & ---- & -0.2412 & 0.0070 \\
\hline impfish & ---- & ---- & ---- & ---- & 0.0094 & 0.1140 \\
\hline$c$ & -0.7865 & 0.0290 & -1.1855 & 0.0050 & 0.3917 & 0.2670 \\
\hline LL* & & -533.52 & & -391.98 & & -195.19 \\
\hline $\mathrm{BIC}^{* *}$ & & $\begin{array}{r}1,084.4 \\
8 \\
\end{array}$ & & 806.05 & & 430.09 \\
\hline Elasticity & & -0.087 & & -0.076 & & -0.027 \\
\hline WTP & & 22.27 & & 25.16 & & 70.55 \\
\hline EB (MD) & & 2.10 & & 2.37 & & 6.65 \\
\hline \multicolumn{7}{|c|}{$\begin{array}{l}* \text { Log-likelihood } \\
* * \text { Bayesian information criterion } \\
* * \text { Consumer surplus } \\
{ }^{*} \text { Economic benefit }\end{array}$} \\
\hline
\end{tabular}

The beyesian information criterion (BIC) mentions that given two models, the model with a smaller BIC will the one that better fitness to the data of University of California, Los Angeles [25]. Based on this premise, the model with better fitness is the Extended III (BIC=430.09).

The price elasticity estimated in the four models is inelastic; there for a variation in the fishing trip cost would entail a minor variation in the sport fishing trips in Los Cabos. The WTP calculated in the Extended model I and II, don't show a significant variation in their values which are between 20.86 and 25.16 dollars. The value of the WTP in the Extended III model is 70.55 dollars, exhibiting a significant difference with respect the other models; nevertheless, this model is the one that fits better to the data. The economic benefits for sport fishing in Los Cabos show the same behaviour as the one calculated for WTP in each model. 


\section{Discussion}

To compare the economic benefits of sport fishing obtained two important values are taken as reference on economic terms. The first one is the Gross Domestic Product (GDP) of the primary sector of BCS for the year 2009, which value was $554 \mathrm{MD}$. The second amount to consider is the value of the fish production of BCS for year 2009, which has the value of 59.4 MD CONAPESCA [26], this value include fish species of a high commercial price such as abalone and lobster; the prices to fisherman was 16.60 and 9.34 dollars $/ \mathrm{kg}$ respectively (Agroprospecta [27]). The value of the benefits of sport fishing estimated with the study is over the primary GDP and under the value of fish production of BCS. Similarly the estimated benefit here is under the calculated by the Billfish Foundation and over the value estimated by Ditton and collaborators.

The CPUE is statistically significant at $99 \%$ in the Extended models I, II and III confirming the assumption that it is an important determinant for the demand model for sport fishing trips in Los Cabos. Its positive symbol indicates that the probability that the individual takes a decision to make a fishing trip will increase if the relative abundance of the fish sport species also increases.

It is important to mention that if the relative abundance of the sport fishing spices decrease, then the probability that a fishing trip would take place would reduce as well. So the results found with respect to CPUE should be considered by the resource managers as a significant element to: i) implement management strategies that help maintain the abundance of the species as it is now, ii) promote the activity in the tourist destination, iii) conservation or the sport fishing species by encouraging and promoting the practice of catch and release and, iv) differential charges for fees or permits.

The inelastic nature of demand functions estimate displays the possibility to suggest increments in the charges for fishing permits, visualizing four options. The first, an increment in the sport fishing permit cost, by day, weekly, monthly or yearly. The second option is the possibility to suggest differentiated charging according to the kind of tourism (national, local or foreign). On third place, one differentiated charge can be given by extraction or release; higher cost for extraction permit and lower cost for release permit. Finally, it is possible to establish differential fees in the permits, depending on the season of the year; higher fees when the likelihood of billfish catch is high and vice versa.

The task becomes difficult to try to answer which of the four WTP should be chosen, the answer is not simple. However, based on statistical criteria, the WTP that should be considered is that calculated by the Extended model III, as it is the one that better fits the data. Keep in mind that economic valuation is static and only responds to the situation prevailing at the time. The value obtained is useful when proposing economic instruments that are able to control the demand on the site, changing patterns of production and consumption (such as catch and release) or establish quotas or permits on catches for the sport fishing species.

On fees or permits on catches, the benefits obtained from this can be oriented to strengthen strategies and management and conservation plans of the cultural 
and recreational ecosystem services that are given by the sport fishing species in Los Cabos.

\section{References}

[1] Chávez-Comparan, J.C. Valoración Económica de los Beneficios Generados por la Pesca Deportiva en Manzanillo, Colima. Memoria del Seminario de Valoración Económica del Medio Ambiente. Dirección de Economía y Política Ambiental. Instituto Nacional de Ecología. México. pp.2-18. 2000.

[2] Comisión Nacional de Acuacultura y Pesca. Boletín Pesquero y Acuícola. Hacia una pesca y acuicultura responsables. "Países Brindan Confianza Total a México. Es un hecho el campeonato mundial de pesca deportiva en Mazatlán". Mayo 31, Año 3, Vol. 47, pp.2. 2009.

[3] Klett-Traulsen A., G. Ponce-Díaz and S. Ortega-García. Pesquería Deportiva Recreativa. Estudio del Potencial Pesquero y Acuícola de Baja California Sur (Chapter 2, Volume II). Casas Váldez and Ponce Díaz (Eds). pp.389-418. 1996.

[4] Gerhard, P. and Gulick, H.E. Lower California Guide Book. Ed. Clark. 83 p. 1962.

[5] Pérez-Valencia, S.A. Estudio de la Pesca Deportivo-Recreativa en la Región de los Cabos, B.C.S., con énfasis en el destino de las capturas. Master Thesis. Centro de Investigaciones Biológicas del Noroeste. La Paz, Baja California Sur, México. 2004.

[6] Ponce-Díaz, G., Ortega-Garcia, S. and Hernández-Vázquez, S. Lunar phase and catch success of the striped marlin (Tetrapturus audax) in sport fishing at Los Cabos, Baja California Sur, Mexico. Revista de Biología Tropical, 51(2). pp.555-559. 2003.

[7] Hernández-Trejo, V.A., Urciaga-García, J., Hernández-Vicent, M.A. and Palos-Arocha, L.O. Valoración económica del Parque Nacional Bahía de Loreto a tráves de los servicios de recreación de pesca deportiva. región y sociedad, Vol. XXI, Num. 44, enero-abril, pp.195-223. 2009.

[8] Ortega-García, S., A. Klett-Traulsen and G. Ponce-Díaz. Analysis of sportfishing catch rates of striped marlin (Tetrapturus audax) at Cabo San Lucas, Baja California Sur, México, and their relation to sea surface tempature. Marine and Freshwater Research, 2003, 54, pp.483-488. 2003.

[9] Turner, K., Pearce, D. and Bateman, I. Environmental economics: an elementary introduction. Harvester Wheatsheaf Eds. Nueva York-London. 1993.

[10] Costanza, R., R., d'Arge; R. de Groot; S. Farber; M. Grasso; B. Hannon; K. Limburg; S. Ñame; R.V. O’Neill; J. Paruelo; J., Raskin, R.G., Raskin, P., van den Belt and M. Marjan. The value of the world's ecosystem services and natural capital. Nature 387, pp.253-260. 1997.

[11] Farber, S., R. Costanza and M.A. Wilson. Economic and ecologic concepts for valuing ecosystem services. Ecological Economics. 41, pp.375-392. 2002. 
[12] Ditton, R.B., Grimes, S.R. and Filkenstein, L.K. A Social and Economic Study of the Recreational Billfish Fishery in the Southern Baja Area of Mexico. Report prepared for The Billfish Foundation. Texas A\&M University. 1996.

[13] Billfish Foundation. Contribución económica de la pesca deportiva a la economía de Los Cabos. p. 43. 2008.

[14] Alberinni, A., Valentina, Z. and Paolo, R. Combining actual and contingent behaviour to estimate the value of sports fishing in the Lagoon of Venice. Ecological Economics, 61 (2007) pp. 530-541. 2007.

[15] Seenprachawong, U. Economic valuation of coral reefs at Phi Phi Islands, Thailand. International Journal of Global Environmental Issues, Vol. 3, No. 1, pp. 104-114. 2003.

[16] Heal, G.M., Barbier, E.B., Boyle, K.J., Gloss, S.P., Hershener, Carlton, H., Hoehn, J.P., Pringle, C.M., Polasky, S., Segerson, K., Shrader-Frechette, K., Gibson, M.C. and De Guaman, E.A. Valuing Ecosystem Services: Toward Better Environmental Decision Making. The National Acadamies Press. p. 291. 2005.

[17] Millennium Ecosystem Assessment. Ecosystems and Human Well-Being. Synthesis. Sarukhán, J. y Reid, W. (Eds.). Island Press. 2005.

[18] Haab, T. and K. McConnel. Valuing Environmental and Natural Resources: The econometrics of non-market valuation. Edward Elgar Publishing. p.326. 2002.

[19] Azqueta-Oyarzun, D. Introducción a la Economía Ambiental. McGraw-Hill Interamericana de España. 2002.

[20] Mäler, K. G. Environmental Economics: A theoretical Inquiry. The Johns Hopkins University Press and Resources for the Future. Baltimore USA. 1974.

[21] Hanley, S.J., Ramson, A.M. and Alistar, D. Is catch-per-unit-effort proportional to abundance? Canadian Journal of Fisheries and Aquatic Sciences, 58 (2001), pp. 1760-1772. 2001.

[22] Maunder, M.N., John, R.S., Alain, F., John, H., Pierre, K. and Shelton, J.H. Interpreting catch per unit effort data to assess the status of individual stocks and communities. ICES Journal of Marine Science, 63:2006, pp. 1373-1385. 2006.

[23] Christiernsson, A. An economic valuation of the coral reefs at Phi Phi Island: a travel cost approach. Essay from Lulea University of Technology. Department of Business Administration and Social Sciences. Division of Economics. p.55. 2003.

[24] Rayson, P. and Garside, R. Comparing corpora using frequency profiling. Proceedings of the workshop on Comparing Corpora, held in conjunction with the 38th annual meeting of the Association for Computational Linguistics (ACL 2000). 1-8 October. Hong Kong. 2000.

[25] University of California, Los Angeles (UCLA). Statistical Consulting Group. UCLA Academic Technology Services. Los Angeles. www.ats.ucla.edu/stat/stata/seminars/count_presentation/count.htm 
[26] Comisión Nacional de Acuacultura y Pesca. Anuario Estadístico. México. 2009.

[27] Agroprospecta. Reporte de Unidades de Producción Acuícola y Pesquera. Red Mexicana de investigación en política agroalimentaria \& SAGARPA (Eds). Panorama económico 2008-2018. Resumen ejecutivo. p.78. 2010. 